WSRC-TR-2001-00322 (Rev 1) (U)

\title{
The Effect of Sedimentation on Plutonium Transport in Fourmile Branch $(\operatorname{Rev} 1)(\mathrm{U})$
}

\author{
K u $0-F u C h$ en
}

Savannah River Technology Center

Publication Date: December 5, 2001

DOES NOT CONTAIN

UNCLASSIFIED CONTROLLED

NUCLEAR INFORMATION

ADC \&

Reviewing

Official:

Date:

\section{Westinghouse Savannah River Company Savannah River Site Aiken, SC 29808}

This document was prepared in connection with work done under Contract No. DE-AC09-96SR18500 with the U. S. Department of Energy 
This document was prepared in conjunction with work accomplished under Contract No. DE-AC09-96SR18500 with the U.S. Department of Energy.

\section{DISCLAIMER}

This report was prepared as an account of work sponsored by an agency of the United States Government. Neither the United States Government nor any agency thereof, nor any of their employees, makes any warranty, express or implied, or assumes any legal liability or responsibility for the accuracy, completeness, or usefulness of any information, apparatus, product or process disclosed, or represents that its use would not infringe privately owned rights. Reference herein to any specific commercial product, process or service by trade name, trademark, manufacturer, or otherwise does not necessarily constitute or imply its endorsement, recommendation, or favoring by the United States Government or any agency thereof. The views and opinions of authors expressed herein do not necessarily state or reflect those of the United States Government or any agency thereof.

This report has been reproduced directly from the best available copy.

Available for sale to the public, in paper, from: U.S. Department of Commerce, National Technical Information Service, 5285 Port Royal Road, Springfield, VA 22161

phone: (800) 553-6847

fax: (703) 605-6900

email: orders@ntis.fedworld.gov

online ordering: $\underline{\text { http://www.ntis.gov/support/index.html }}$

Available electronically at $\mathrm{http}: / / \mathrm{www}$. doe.gov/bridge

Available for a processing fee to U.S. Department of Energy and its contractors, in paper, from: U.S. Department of Energy, Office of Scientific and Technical Information, P.O. Box 62, Oak Ridge, TN 37831-0062

phone: (865)576-8401

fax: $(\mathbf{8 6 5}) 576-5728$

email: reportseadonis.osti.gov 
WSRC-TR-2001-00322 (Rev 1)

December 5, 2001

\section{The Effect of Sedimentation on Plutonium Transport in Fourmile Branch (Rev 1) (U)}

Kuo-Fu Chen, Author, MTD/ N TS

WestinghouseSavannah River Company

D. P. Griggs, Technical Reviewer, MTD/ NTS

WestinghouseSavannah River Company

Approved by:

R. P. Addis, Manager, MTD/ ATG

WestinghouseSavannah River Company

A. L. Boni, Manager, MTD/ NTS

WestinghouseSavannah River Company

Prepared for the U.S. Department of Energy under Contract no. DE-AC09-96SR18500 


\section{ABSTRACT}

The major mechanisms of radioactive material transport and fate in surface water are: 1) sources, 2) dilution, advection and dispersion of radionuclides by flow and surface waves, 3) radionuclide decay, and 4) interaction between sediment and radionuclides. STREAM II, an aqueous transport module of the Savannah River Site emergency response WIND system, accounts for the source term, and the effects of dilution, advection and dispersion. Although the model has the capability to account for nuclear decay, due to the short time interval of interest for emergency response, the effect of nuclear decay is very small and so it is not employed. The interactions between the sediment and radionuclides are controlled by the flow conditions and physical and chemical characteristics of the radionuclides and the sediment constituents. The STREAM II version used in emergency response must provide results relatively quickly; it therefore does not model the effects of sediment deposition/resuspension.

This study estimates the effects of sediment deposition/resuspension on aqueous plutonium transport in Fourmile Branch. There are no measured data on plutonium transport through surface water available for direct model calibration. Therefore, a literature search was conducted to find the range of plutonium partition coefficients based on laboratory experiments and field measurements. A sensitivity study of the calculated plutonium peak concentrations as a function of the input parameter of partition coefficient was then performed. Finally, an estimation of the plutonium partition coefficient was made for the Fourmile Branch.

A plutonium partition coefficient for Fourmile Branch is estimated, using measured partition coefficients for cesium and assuming linear relationships between plutonium and cesium concentrations in the dissolved phase as well as in the sediment. In the original report (Rev. 0), measured plutonium and cesium concentrations in Fourmile Branch water and sediment were used to establish these linear relationships. Subsequent examination of the dissolved concentration data revealed that most of the measurements were too low to be statistically significant and, therefore, could not be used to support the assumed linear relationship. Conversely, the sediment data were found to be viable for relating plutonium and cesium concentrations. In the current work (Rev. 1), data from Lake Michigan are used to establish the linear relationship between plutonium and cesium concentrations in the dissolved phase.

A plutonium partition coefficient of $15,344 \mathrm{ml} / \mathrm{g}$ was estimated for the Fourmile Branch. At this partition coefficient, the calculated peak concentration reduction relative to the case not accounting for the sedimentation effect is $27 \%$ near Road E, and the reduction increases to $87 \%$ at Road C-4. Road C-4 is at 3.15 miles downstream from the discharge location. The validity of this estimation needs to be qualified by field measurements.

This study indicates that the downstream plutonium peak concentration is reduced significantly by the physical phenomenon of sediment deposition/resuspension. Therefore, neglecting sedimentation effects in STREAM II is conservative with respect to estimating downstream peak concentration for emergency response. 


\section{TABLE OF CONTENTS}

1. Introduction 1

2. Model Description 1

2.1 Plutonium Partition Coefficient 2

3. Results 3

3.1 Estimation of Plutonium Partition Coefficient for Fourmile Branch 3

4. Conclusions 6

$\begin{array}{ll}\text { References } & 8\end{array}$ 


\section{LIST OF TABLES}

$\begin{array}{llr}\text { Table } 1 & \text { Model Geometry } & 10\end{array}$

Table 2 Calculated Plutonium Peak Concentrations 11

Table 3 Cesium Partition Coefficient for Nitelva River Sediments 11

\section{LIST OF FIGURES}

Figure 1 Fourmile Branch Region Below the Separations Area at SRS 12

Figure 2 Model Schematics for Fourmile Branch (not to scale) 13

Figure 3 Effect of $\mathrm{pH}$ and Plutonium Oxidation State on Soil Adsorption of Plutonium

Figure 4 Percent Reduction of Calculated Plutonium Peak Concentration as a Function of Partition Coefficient (Reduction relative to the case not including the sediment deposition/resuspension effect)

Figure 5 Relationship Between the Measured Radioactivity of Cs-137 and Pu-238 in the Fourmile Branch Sediment

Figure 6 Relative annual fallout radionuclide inputs (lower histogram) and cumulative total input (upper histogram) for Lake Michigan, 1960-1974, and fraction of total Pu-239 and Cs-137 inputs remaining in the water during 1966-1974 (data points and straight lines)

Figure 7 Curve Fit of the Cesium Partition Coefficient as a Function of Sediment Concentration (Data from Table 3) 


\section{Introduction}

The major mechanisms of radioactive material transport and fate in surface water are: 1) sources, 2) dilution, advection and dispersion of radionuclides by flow and surface waves, 3) radionuclide decay, and 4) interaction between sediment and radionuclides. The interactions between sediment and radionuclides include radionuclide adsorption by sediment, radionuclide desorption from sediment to water, transport of particulate radionuclides (those adsorbed by suspended sediment), deposition of particulate radionuclides to streambed (benthic layer), and scouring of particulate radionuclides from stream bed (resuspension).

STREAM II [1], an aqueous transport module of the Savannah River Site (SRS) emergency response WIND system, accounts for the source term and the effects of dilution, advection and dispersion. Although the model has the capability to account for nuclear decay, due to the short time interval of interest for emergency response, the effect of nuclear decay is very small and so it is not employed. The interactions between the sediment and radionuclides are controlled by the flow conditions and physical and chemical characteristics of the radionuclides and the sediment constituents. The STREAM II version used in emergency response does not model the effects of sediment deposition/resuspension.

The effect of sedimentation on cesium transport in Fourmile Branch was studied in Reference 2 based on the dye tracer data measured by Kiser in 1978 [3]. This report is a continuation of the work in Reference 2 investigating the sediment deposition/resuspension effect on plutonium aqueous transport. Reference 2 indicated that the calculated cesium peak concentrations were influenced by the sediment concentration in the stream and the partition coefficient. There are no measured data on plutonium transport through surface water available for direct model calibration. Therefore, the model developed in Reference 2 but with a different partition coefficient was used to estimate the plutonium peak concentration reductions due to the effect of sedimentation. In this report, a literature search was conducted to find the range of plutonium partition coefficients based on laboratory experiments and field measurements, and a sensitivity study was performed by varying the input partition coefficient. Finally, a plutonium partition coefficient for Fourmile Branch was estimated, using measured partition coefficients for cesium and assuming linear relationships between plutonium and cesium concentrations in the dissolved phase as well as in the sediment. In the original report (Rev. 0), measured plutonium and cesium concentrations in Fourmile Branch water and sediment were used to establish these linear relationships. Subsequent examination of the dissolved concentration data revealed that most of the measurements were too low to be statistically significant and, therefore, could not be used to support the assumed linear relationship. Conversely, the sediment data were found to be viable for relating plutonium and cesium concentrations. In the current work (Rev. 1), data from Lake Michigan are used to establish the linear relationship between plutonium and cesium concentrations in the dissolved phase.

\section{Model Description}

As described in Reference 1, the calculation module of WASP5 [4] was adapted in STREAM II to perform the calculations for contaminant transport through the SRS streams and Savannah River. A special input model was developed to examine the effects of sediment 
deposition/resuspension on downstream contaminant concentrations. For convenience, a WASP5 model including sediment deposition/resuspension effects was developed to model Kiser's dye tracer study in Reference 2. In Kiser's study, one liter of 20\% Rhodamine WT dye (about $200 \mathrm{~g}$ of dye) was released to Fourmile Branch at Road E near H-Area at about 9 AM. One hour after the dye release, 130 grams of cesium chloride (about $100 \mathrm{~g}$ of ${ }^{133} \mathrm{Cs}$ ) were released at the same location as the dye. The dye and cesium concentrations were measured at downstream locations. Figure 1 shows the map of Kiser's dye study. The WASP5 model developed in Reference 2 is summarized next.

Figure 2 and Table 1 from Reference 2 presents the WASP5 model simulation of the Fourmile Branch reach from upstream of Road E to Road A7 (downstream from Road C-4). The input flow was 31.2 1/s from Segments 1 to 245, 144.4 1/s from Segments 246 to 319, and 237.9 1/s from Segments 320 to 875 . The input dispersion coefficients are $0.05 \mathrm{~m}^{2} / \mathrm{sec}$ from Segments 1 to $245,0.0 \mathrm{~m}^{2} / \mathrm{sec}$ (numerical diffusion is sufficient) from Segments 246 to $319,5.0 \mathrm{~m}^{2} / \mathrm{sec}$ from Segments 320 to 603 , and $80.0 \mathrm{~m}^{2} / \mathrm{sec}$ from Segments 604 to 875 , as shown in Table 1 . The time step was 0.0001 day ( 8.64 seconds). The diffusion coefficient between the water column and the benthic layer was $1.0 \mathrm{E}-04 \mathrm{~cm}^{2} / \mathrm{s}$.

The concentrations of the suspended sediment in the water column segments were $20 \mathrm{ppm}$ and the sediment concentrations in the benthic segment were $1.0 \mathrm{E}+06 \mathrm{mg} / \mathrm{l}$. The settling velocity was $35 \mathrm{~m} /$ day for Segments 1 to 264 . The stream material for Segments 1 to 264 was sand. The settling velocity for Segments 265 to 444 (silt) was $20 \mathrm{~m} /$ day, and the settling velocity for Segments 445 to 875 (clay) was $0.15 \mathrm{~m} /$ day. The resuspension velocities were $7.0 \mathrm{E}-04 \mathrm{~m} / \mathrm{day}$ for Segments 1 to 264, 4.0E-04 m/day for Segments 265 to 444, and 3.0E-06 m/day for Segments 445 to 875 .

The WASP5 model from Reference 2 was used to model the plutonium transport except the partition coefficient was varied. The partition coefficient for plutonium is different than that of cesium. A partition coefficient appropriate for plutonium was required to simulate plutonium transport in the Fourmile Branch.

\subsection{Plutonium Partition Coefficient}

Prout [5, 6] determined the plutonium partition coefficient experimentally at the Savannah River Laboratory in the late 1950s. In Prout's experiment, the partition coefficients were determined by mixing the local soil ( $80 \%$ sand to $20 \%$ clay, in which the clay mineral kaolinite is dominant) into radioactive plutonium solutions $\left(\sim 10^{-6} \mathrm{M}\right)$ at various plutonium oxidation states and solution $\mathrm{pH}$ values. The mixture ( $10 \mathrm{~g}$ of soil and $100 \mathrm{ml}$ of solution) was shaken two hours by a mechanical shaker before the mixture was phase separated by centrifugation. The samples were centrifuged and aliquots of the supernatant liquid were removed to determine the concentration of the radioactive plutonium. The amount of the radioactive plutonium isotope adsorbed by the soil was the difference between the solution activity before and after mixing with soil. Figure 3 shows the plutonium equilibrium adsorption data as a function of solution $\mathrm{pH}$ and plutonium oxidation states. The average measured $\mathrm{pH}$ at Fourmile Branch (FM-6) from 1990 to 1999 was 6.6. Based on Figure 3, the plutonium partition coefficient (Kd) in Fourmile Branch could vary from 80 to $>10,000 \mathrm{ml} / \mathrm{g}$ at a $\mathrm{pH}$ of 6.6 . 
Onishi et al. [7] reported field measured plutonium partition coefficients by several researchers. Wahlgren and Nelson [8] calculated the Kd for Pu on suspended particles within Great Miami River to be $\geq 100,000 \mathrm{ml} / \mathrm{g}$. Hetherington [9], Hetherington et al. [10], and Templeton and Preston [11] studied the migration of plutonium discharged from the reprocessing plant at Windscale. The observed field $\mathrm{Kd}$ was $1,000 \mathrm{ml} / \mathrm{g}$ for sand and 200,000 for fine muck. Sedlet and Golchert [12] measured the Pu-239 and Pu-240 in the creek and rivers near Argonne National Laboratory. The field Kd was 2,000 ml/g for Sawmill, 40,000 ml/g for De Plaines River, and 3,000 $\mathrm{ml} / \mathrm{g}$ for Illinois River.

\section{Results}

The WASP5 model developed in Reference 2 was used to simulate the transport of $100 \mathrm{~g}$ of plutonium released to Fourmile Branch at Road E near H-Area. As described in Section 2.1, the value of the plutonium partition coefficient varies widely from 1,000 to $200,000 \mathrm{ml} / \mathrm{g}$. Therefore, the measurement of a site-specific partition coefficient and/or a tracer study is required to accurately estimate the effect of sedimentation on plutonium transport in Fourmile Branch. Without the measured plutonium partition coefficient for Fourmile Branch, a sensitivity study was performed by varying the plutonium partition coefficient to estimate the effect of the sedimentation as a function of partition coefficient. Ten cases were simulated. The baseline case did not include the sediment deposition/resuspension effect in the plutonium transport simulation. The sediment deposition/resuspension effect was simulated for the remaining nine cases by varying the partition coefficient from 3,000 to $200,000 \mathrm{ml} / \mathrm{g}$. In each case, the assumed suspended sediment concentration was $20 \mathrm{ppm}$.

Table 2 shows the calculated total plutonium peak concentrations (dissolved in water and adsorbed on suspended solids) at downstream locations for various partition coefficients. For the case not including the sedimentation effect, the calculated peak concentration near Road $\mathrm{E}$ is $4,622.00 \mu \mathrm{g} / \mathrm{l}$ and the calculated peak concentration drops to $27.50 \mu \mathrm{g} / \mathrm{l}$ at Road C-4 as plutonium transports downstream. The calculated total peak concentration decreases when the partition coefficient increases. For the case of a partition coefficient of $200,000 \mathrm{ml} / \mathrm{g}$, the calculated peak concentration near Road E is $1,600.00 \mu \mathrm{g} / \mathrm{l}$ and the calculated peak concentration is $0.03 \mu \mathrm{g} / \mathrm{l}$ at Road C-4. Figure 4 presents the percent reduction of the calculated downstream peak concentration as a function of partition coefficients. The percent reduction is relative to the baseline case that did not include the sediment deposition/resuspension effect in the simulation. Table 2 and Figure 4 indicate that the reduction of downstream plutonium concentrations is strongly influenced by the partition coefficient. Therefore, a site-specific partition coefficient is required to accurately estimate the effect of sedimentation on downstream peak concentrations.

\subsection{Estimation of Plutonium Partition Coefficient for Fourmile Branch}

This section presents an estimation of the plutonium partition coefficient for Fourmile Branch using available knowledge. The validity of this result needs to be qualified by field measurements. 
The average measured $\mathrm{pH}$ at Fourmile Branch (FM-6) from 1990 to 1999 was 6.6. Based on Figure 3, the plutonium partition coefficient (Kd) in Fourmile Branch could vary from 80 to $>10,000 \mathrm{ml} / \mathrm{g}$ at a pH of 6.6. However, the mixture used in Prout's experiments is $10 \mathrm{~g}$ soil to $100 \mathrm{ml}$ solution. This mixture is equivalent to a sediment concentration of $100,000 \mathrm{ppm}$, significantly higher than the sediment concentrations in a stream. The measured average sediment concentration is $20 \mathrm{ppm}$ for Fourmile Branch [2]. The purpose of Prout's experiment was to determine the reduction of radioactive isotopes as radioactive liquid waste percolates downward through the soil layer from the seepage basin. Therefore, the soil concentration used in Prout's experiment is very high relative to the sediment concentrations in the streams. Table 3 shows that the cesium partition coefficient increases as sediment concentration decreases on Nitelva River, Norway [7]. Based on the data shown in Table 3, it is quite possible that the plutonium partition coefficient for the Fourmile Branch should be much higher than that presented in Figure 3.

In addition to Prout's data, a plutonium partition coefficient of 5,000 $\mathrm{ml} / \mathrm{g}$ was measured by Mudge et al. for River Esk water at a sediment concentration of $860 \mathrm{ppm}$ [13]. The next task is to estimate the plutonium partition coefficient at the sediment concentration of $20 \mathrm{ppm}$. One assumption was used to estimate the plutonium partition coefficient at the sediment concentration of $20 \mathrm{ppm}$. Since plutonium and cesium are closely associated in sediments and follow similar surface water transport pathways, the variation with sediment concentration of the cesium Kd for adsorption in fresh water can be used to estimate the fresh water adsorption $\mathrm{Kd}$ for plutonium. This assumption needs to be qualified by the field measurements.

The partition coefficient is the ratio between the mass adsorbed per unit mass of sediment to the mass dissolved per unit volume of water. Equation 1 is the partition coefficient for cesium.

$$
\mathrm{Kd}_{\mathrm{Cs}}=\frac{\chi_{\mathrm{Cs}}^{\mathrm{s}}}{\mathrm{C}_{\mathrm{Cs}}^{\mathrm{L}}}
$$

where, $\mathrm{Kd}_{\mathrm{Cs}}$ is cesium partition coefficient, $\chi_{\mathrm{Cs}}^{\mathrm{S}}$ is cesium mass adsorbed on per unit mass of sediment, and $\mathrm{C}_{\mathrm{Cs}}^{\mathrm{L}}$ is the dissolved cesium mass per unit volume of water. In the same fashion, the partition coefficient for plutonium is expressed in Equation 2.

$$
\mathrm{Kd}_{\mathrm{Pu}}=\frac{\chi_{\mathrm{Pu}}^{\mathrm{S}}}{\mathrm{C}_{\mathrm{Pu}}^{\mathrm{L}}}
$$

The radioactivities measured for the cesium and plutonium in the Fourmile Branch sediment and in the Fourmile Branch water were obtained from the Savannah River Site Environmental Reports from 1993 to 1999 [14-20]. Figure 5 shows the linear relationship between the measured radioactivity of $\mathrm{Cs}-137$ and $\mathrm{Pu}-238$ in the Fourmile Branch sediment. From Figure 5, it could be assumed that $\chi_{\mathrm{Pu}}^{\mathrm{S}}$ is proportional to $\chi_{\mathrm{Cs}}^{\mathrm{S}}$ in the Fourmile Branch sediment, as shown in Equation 3. 
$\chi_{\mathrm{Cs}}^{\mathrm{S}}=\mathrm{a} \chi_{\mathrm{Pu}}^{\mathrm{S}}$

where, a is a proportionality factor.

Figure 6 shows the relative annual inputs of fallout radioactivity to Lake Michigan, the accumulated total fallout radioactivity to Lake Michigan, and the measured Pu-239 and Cs-137 concentrations of the Lake Michigan water during 1971 to 1974 [21]. The slopes of the plutonium and the cesium concentrations shown in Figure 6 are approximately the same. Given the water concentrations of plutonium and cesium in Reference 21, it is assumed that the dissolved plutonium concentration $\left(\mathrm{C}_{\mathrm{Pu}}^{\mathrm{L}}\right)$ is proportional to the dissolved cesium concentration $\left(\mathrm{C}_{\mathrm{Cs}}^{\mathrm{L}}\right)$ in the fresh water. Equation 4 shows the assumed relationship.

$$
\mathrm{C}_{\mathrm{Cs}}^{\mathrm{L}}=\mathrm{bC}_{\mathrm{Pu}}^{\mathrm{L}}
$$

where, $\mathrm{b}$ is a proportionality factor.

After substituting Equations 3 and 4 into Equation 1, Equation 1 becomes Equation 5.

$$
\mathrm{Kd}_{\mathrm{Cs}}=\frac{\mathrm{a} \chi_{\mathrm{Pu}}^{\mathrm{s}}}{\mathrm{bC}_{\mathrm{Pu}}^{\mathrm{L}}}=\alpha \mathrm{Kd}_{\mathrm{Pu}}
$$

where, $\alpha$ is a divided by $b$.

Equation 5 shows that the plutonium partition coefficient is proportional to the cesium partition coefficient.

The steps used to estimate the plutonium partition coefficient at a sediment concentration of 20 ppm are presented next.

Step 1:

Equation 6, the relationship between the cesium partition coefficient and the sediment concentration, was derived by curve fitting the data presented in Table 3, as shown in Figure 8.

$$
\mathrm{Kd}_{\mathrm{Cs}}=20261.0919 \mathrm{C}^{-0.298117746}
$$

where $\mathrm{Kd}_{\mathrm{Cs}}$ is cesium partition coefficient in $\mathrm{ml} / \mathrm{g}$, and $\mathrm{C}$ is sediment concentration in $\mathrm{ppm}$.

\section{Step 2:}

Based on the assumption that the shape of the partition coefficient vs. the sediment concentration for plutonium is the same as that for cesium, the relationship between the plutonium partition coefficient and the sediment concentration could be expressed as Equation 7. 
$\mathrm{Kd}_{\mathrm{Pu}}=\mathrm{F} 20261.0919 \mathrm{C}^{-0.298117746}$

where $\mathrm{Kd}_{\mathrm{Pu}}$ is plutonium partition coefficient in $\mathrm{ml} / \mathrm{g}, \mathrm{C}$ is sediment concentration in ppm, and $\mathrm{F}$ is a conversion constant. From Reference 13, the plutonium partition coefficient at a sediment concentration of $860 \mathrm{ppm}$ is $5,000 \mathrm{ml} / \mathrm{g}$. The conversion constant, $\mathrm{F}$, was calculated as 1.849836, after substituting 5,000 for $\mathrm{Kd}_{\mathrm{Pu}}$ and 860 for $\mathrm{C}$ into Equation 7. After substituting the value of $\mathrm{F}$ into Equation 7, the function for plutonium partition coefficient is obtained, as Equation 8.

$$
\mathrm{Kd}_{\mathrm{Pu}}=37479.701562 \mathrm{C}^{-0.298117746}
$$

For the sediment concentrations of 20 and 100,000 ppm, the calculated plutonium partition coefficients by Equation 3 are 15,344 and 1,211 ml/g, respectively. The plutonium partition coefficient of $1,211 \mathrm{ml} / \mathrm{g}$ at the sediment concentration of $100,000 \mathrm{ppm}$ is within the range of the partition coefficients measured by Prout, as shown in Figure 3.

For a partition coefficient of 15,344 $\mathrm{ml} / \mathrm{g}$, the calculated peak concentration near Road E (about 140 meters downstream from the release point) is 3,361 $\mu \mathrm{g} / \mathrm{l}$, and at Road C-4 (about 5075 meters downstream from the release point) is $3.63 \mu \mathrm{g} / \mathrm{l}$. The reduction of the calculated peak concentration near Road E is $27 \%$ and at Road C-4 is $87 \%$ relative to the baseline case of not accounting for the sedimentation effect. Field measurements of the plutonium partition coefficient are required to accurately estimate the effect of sediment deposition/resuspension on the transport of plutonium in the Fourmile Branch.

\section{Conclusions}

Reference 2 models the effect of sedimentation on cesium transport in Fourmile Branch based on the dye tracer data measured by Kiser in 1978 [3]. The current work is a continuation of Reference 2 investigating the sediment deposition/resuspension effect on plutonium aqueous transport. Reference 2 indicated that the calculated cesium peak concentrations were influenced by the suspended solid concentration in the stream and the partition coefficient. There is no measured data about plutonium transport through surface water available for direct model calibration. Therefore, the model developed in Reference 2 was used to estimate the plutonium peak concentration reductions due to the effect of sedimentation. In this report, a literature search was conducted to find the range of plutonium partition coefficients based on laboratory experiments and field measurements, and a sensitivity study was performed by varying the partition coefficient in the model. The cases simulated a release of $100 \mathrm{~g}$ plutonium to Fourmile Branch at Road E near H-Area. Without the sedimentation effect, the calculated peak concentration near Road E is $4622.00 \mu \mathrm{g} / \mathrm{l}$ and the calculated peak concentration drops to 27.50 $\mu \mathrm{g} / \mathrm{l}$ at Road C-4. For the case of a partition coefficient of $200,000 \mathrm{ml} / \mathrm{g}$, the calculated peak concentration near Road E is $1600.00 \mu \mathrm{g} / \mathrm{l}$ and the calculated peak concentration drops to 0.03 $\mu \mathrm{g} / \mathrm{l}$ at Road C-4. These results indicate that the reduction of downstream plutonium concentrations is strongly influenced by the partition coefficient. Therefore, a site-specific 
partition coefficient is required to accurately estimate the effect of sedimentation on downstream peak concentrations

A plutonium partition coefficient of $15,344 \mathrm{ml} / \mathrm{g}$ was estimated for the Fourmile Branch. At this partition coefficient, the calculated peak concentration reduction relative to the case not accounting for the sedimentation effect is $27 \%$ near Road E, and the reduction increases to $87 \%$ at Road C-4. Road C-4 is at 3.15 miles downstream from the discharge location. The validity of this estimation needs to be qualified by field measurements.

This study indicates that the downstream plutonium peak concentration is reduced significantly by the physical phenomenon of sediment deposition/resuspension. Therefore, neglecting sedimentation effects in STREAM II is conservative with respect to estimating downstream peak concentration for emergency response. 


\section{REFERENCES}

1. Chen, Kuo-Fu, "STREAM II Revision 1: An Aqueous Release Emergency Response Model (U)," WSRC-TR-2000-00072, March 2000.

2. Chen, Kuo-Fu, "Modeling the Effect of Sedimentation on Cesium Transport in Fourmile Branch (U),", Westinghouse Savannah River Company, Aiken, South Carolina, WSRCTR-2000-00380, September 30, 2000.

3. Kiser, D. L., "Cesium Transport in Four Mile Creek of the Savannah River Plant," Savannah River Laboratory, Aiken, South Carolina, DP-1528, April 1979.

4. Robert B. Ambrose, Tim A. Wool, and James L. Martin, "The Water Quality Analysis Simulation Program, WASP5, Part A: Model Documentation; Part B: Input Dataset," Environmental Research Laboratory, Office of Research and Development, U.S. Environmental Protection Agency, Athens, Georgia, September 20, 1993.

5. Prout, W. E., “Adsorption of Radioactive Waste by Savannah River Plant Soil,” Soil Science 86:13-17, 1958.

6. Prout W. E., “Adsorption of Fission Products by Savannah River Plant Soil,” E. I. Du Pont de Nemours \& Co., Savannah River Laboratory, Aiken, South Carolina, July, 1958.

7. Onishi, Y., R. J. Serne, E. M. Arnold, C. E. Cowan, and F. L. Thompson, "Critical Review: Radionuclide Transport, Sediment Transport, and Water Quality Mathematical Modeling; and Radionuclide Adsorption/Desorption Mechanisms," Pacific Northwest Laboratory, Battelle Memorial Institute, NUREG/CR-1322, PNL-2901,January, 1981.

8. Wahlgren, M. A., and D. M. Nelson, A Comparison of the Distribution Coefficients of Plutonium and Other Radionuclides in Lake Michigan to Those in Other Systems. ANL76-88 Part III, PP. 56-60, 1976.

9. Hetherington, J. A. "Chapter 5. The Behavior of Plutonium Nuclides in the Irish Sea," In: Environmental Toxicity of Aquatic Radionuclides: Models and Mechanisms. Rochester International Conference on Environmental Toxicity, $8^{\text {th }}, 1975$.

10. Hetherington, J. A., D. F. Jefferies, N. J. Mitchell, R. J. Pentreath and D. S. Woodhead, Environmental and Public Health Consequences of the Controlled Disposal of Transuranic E;lements to the Marine Environment. IAEA-SM-199/11, 1975

11. Templeton, W. L. and A. Preston, "Disposal of Radioactive Waters into Sea, Oceans and Surface Waters,” In: IAEA Publication, pp. 267-289, 1966.

12. Sedlet, J. and N. W. Golchert, "Environmental Monitoring for Some Transuranium Elements." Presented at $4^{\text {th }}$ International Congress of the International Radiation Protection Association, Paris, France, April 24-30, 1977 (CONF 770409-5), 1977 
13. Mudge, S., J. Hamilton-Taylor, M. Kelly, and K. Bradshaw, "Laboratory Studies of Chemical Behavior of Plutonium Associated with Contaminated Estuarine Sediment," Journal Environmental Radioactivity 8, pp 217-237, 1988.

14. Savannah River Site Environmental Data for 1993, WSRC-TR-94-077, 1994.

15. Savannah River Site Environmental Data for 1994, WSRC-TR-95-077, 1995.

16. Savannah River Site Environmental Data for 1995, WSRC-TR-96-0077, 1996.

17. Savannah River Site Environmental Data for 1996, WSRC-TR-97-0077, 1997.

18. Savannah River Site Environmental Data for 1997, WSRC-TR-97-00324, 1997.

19. Savannah River Site Environmental Data for 1998, WSRC-TR-98-00314, 1998.

20. Savannah River Site Environmental Data for 1999, WSRC-TR-99-00301, 1999.

21. Wahlgren, M. A., and J. S. Marshall, "The Behavior of Plutonium and other Long-Lived Radionuclides in Lake Michigan: I. Biological transport, seasonal cycling, and resident times in the water column," in Proceedings of International Symposium on Radiological Impacts of Releases from Nuclear Facilities into Aquatic Environments, Otaniemal, Finland, 30 June - 4 July 1975, International Atomic Energy Agency. 


\section{Table 1 Model Geometry}

Water Column Segments

Segment ID

1 to 245

246 to 319

320 to 603

604 to 875

876 to $878^{*}$
Cross Sectio
$\left(\mathrm{m}^{2}\right)$

0.3

2.6

1.4

1.4

1.4
Segment Length

(m)

5

5

10

10

10
Volume

$\left(\mathrm{m}^{3}\right)$

1.5

13.0

14.0

14.0

14.0
Dispersion Coefficient $\left(\mathrm{m}^{2} / \mathrm{s}\right)$

0.05

0.0

5.0

80.0

0.0

*Segments 876 to 878 provide input tributary flows only.

Benthic Segments

$\begin{array}{lcccc}\begin{array}{c}\text { Segment } \\ \text { ID }\end{array} & \begin{array}{c}\text { Cross Section Area** } \\ \left(\mathrm{m}^{2}\right)\end{array} & \begin{array}{c}\text { Depth }^{+} \\ (\mathrm{m})\end{array} & \begin{array}{c}\text { Volume } \\ \left(\mathrm{m}^{3}\right)\end{array} & \begin{array}{c}\text { Dispersion Coefficient } \\ \left(\mathrm{m}^{2} / \mathrm{s}\right)\end{array} \\ 879 \text { to } 1123 & 3.75 & 0.1 & 0.375 & 1.0 \mathrm{E}-08 \\ 1124 \text { to } 1197 & 11.04 & 0.1 & 1.104 & 1.0 \mathrm{E}-08 \\ 1198 \text { to } 1753 & 16.20 & 0.1 & 1.620 & 1.0 \mathrm{E}-08\end{array}$

**Area between water column segment and the benthic segment.

${ }^{+}$Depth of the benthic layer.

From Reference 2 
Table 2. Calculated Plutonium Peak Concentrations ${ }^{+}$

\begin{tabular}{|c|c|c|c|c|}
\hline $\begin{array}{l}\mathrm{Kd} \\
\mathrm{ml} / \mathrm{g}\end{array}$ & $\begin{array}{l}\text { Road E } \\
\mu \mathrm{g} / \mathrm{l}\end{array}$ & $\begin{array}{r}\text { Road } 4 \\
\mu \mathrm{g} / 1\end{array}$ & $\begin{array}{r}\text { Road C } \\
\mu \mathrm{g} / 1\end{array}$ & $\begin{array}{c}\text { Road C-4 } \\
\mu \mathrm{g} / \mathrm{l}\end{array}$ \\
\hline * & 4622.00 & 419.70 & 86.23 & 27.50 \\
\hline 3000 & 4280.00 & 304.80 & 53.15 & 16.83 \\
\hline 6000 & 3997.00 & 229.30 & 34.56 & 10.88 \\
\hline 6334 & 3968.00 & 222.50 & 33.04 & 10.39 \\
\hline 10000 & 3687.00 & 164.00 & 20.85 & 6.52 \\
\hline 15344 & 3361.00 & 112.00 & 11.71 & 3.63 \\
\hline 20000 & 3143.00 & 84.30 & 7.63 & 2.35 \\
\hline 50000 & 2370.00 & 25.70 & 1.27 & 0.38 \\
\hline 100000 & 1910.00 & 10.30 & 0.32 & 0.09 \\
\hline 200000 & 1600.00 & 4.99 & 0.11 & 0.03 \\
\hline
\end{tabular}

$+100 \mathrm{~g}$ plutonium released to Fourmile Branch at Road E near H-Area.

* Calculation not including the sediment deposition/resuspension effect.

Table 3 Cesium Partition Coefficient for Nitelva River Sediments

Sediment Concentration (ppm)

16

32

64

128

256
Partition Coefficient $(\mathrm{ml} / \mathrm{g})$

8,900

7,300

5,500

5,000

3,900

From Reference 6 
Figure 1 Fourmile Branch Region Below the Separation Area at SRS

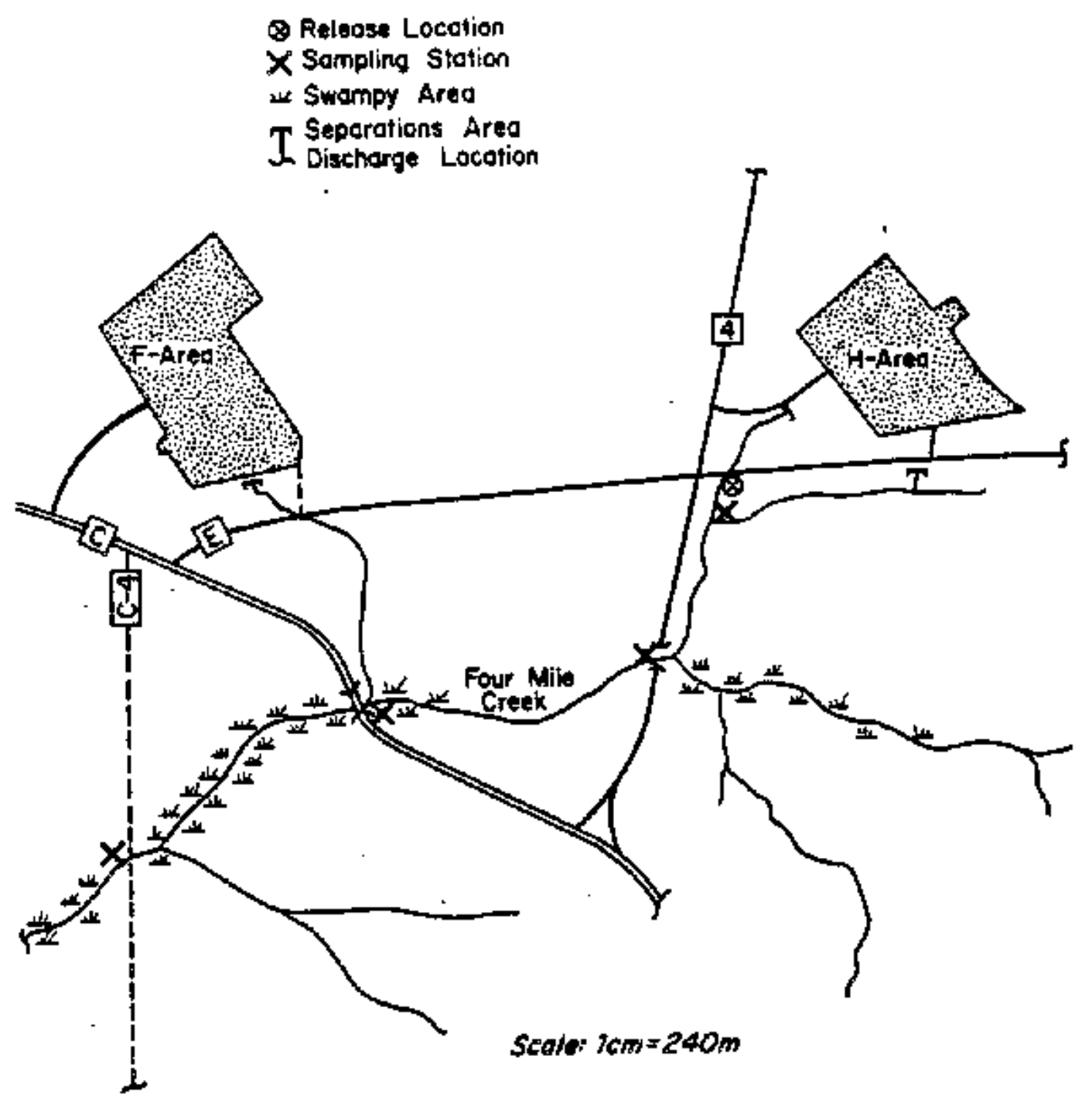


Figure 2. Model Schematics for Sediment Deposition/Resuspension (not to scale)
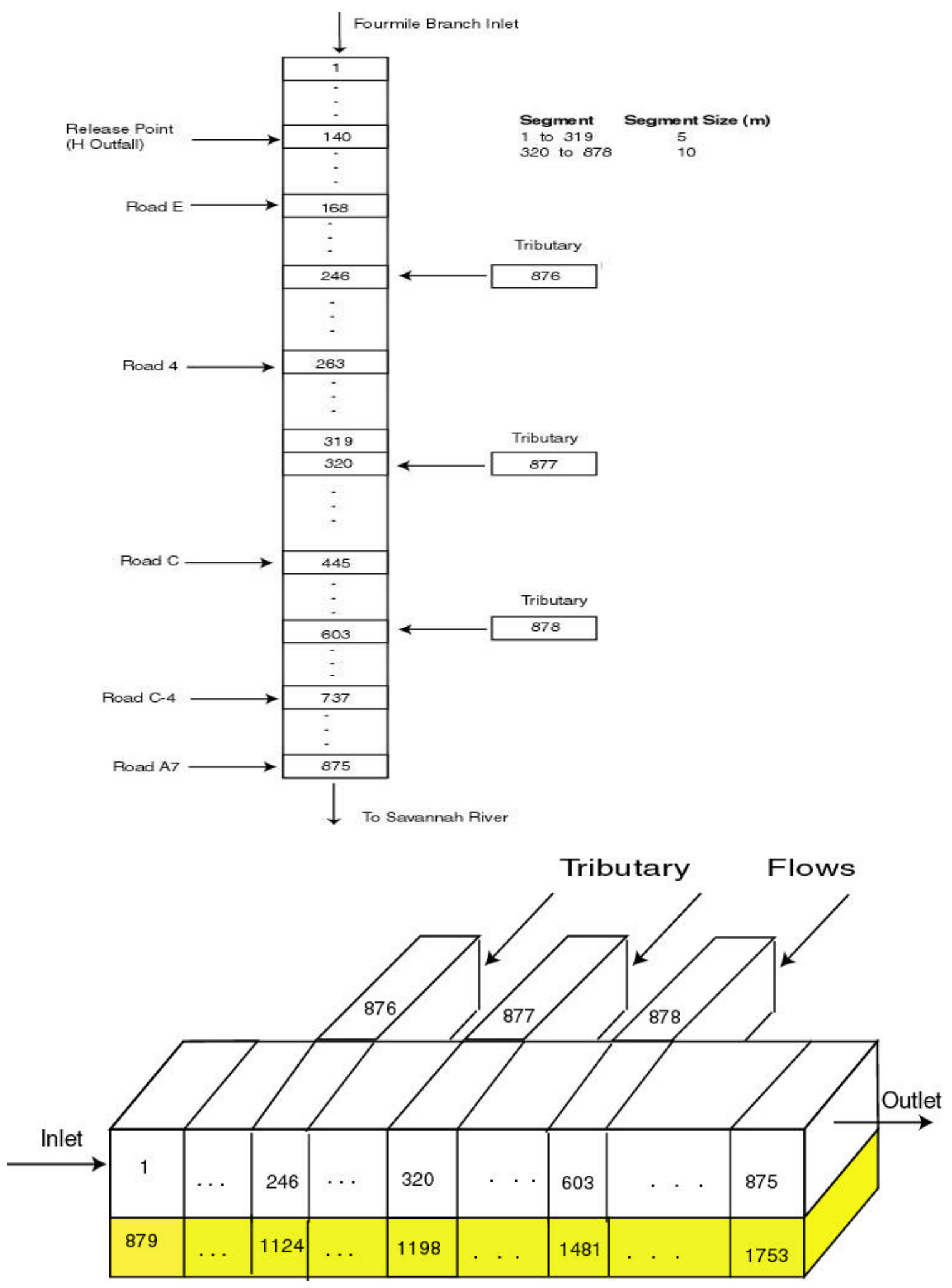
Figure 3. Effect of $\mathrm{pH}$ and Plutonium Oxidation State on the Soil Adsorption of Plutonium $[\mathrm{Pu}]=3 \mathrm{E} 6 \mathrm{~d} / \mathrm{m} / \mathrm{ml}\left(\cong 10^{-6} \mathrm{M}\right)$

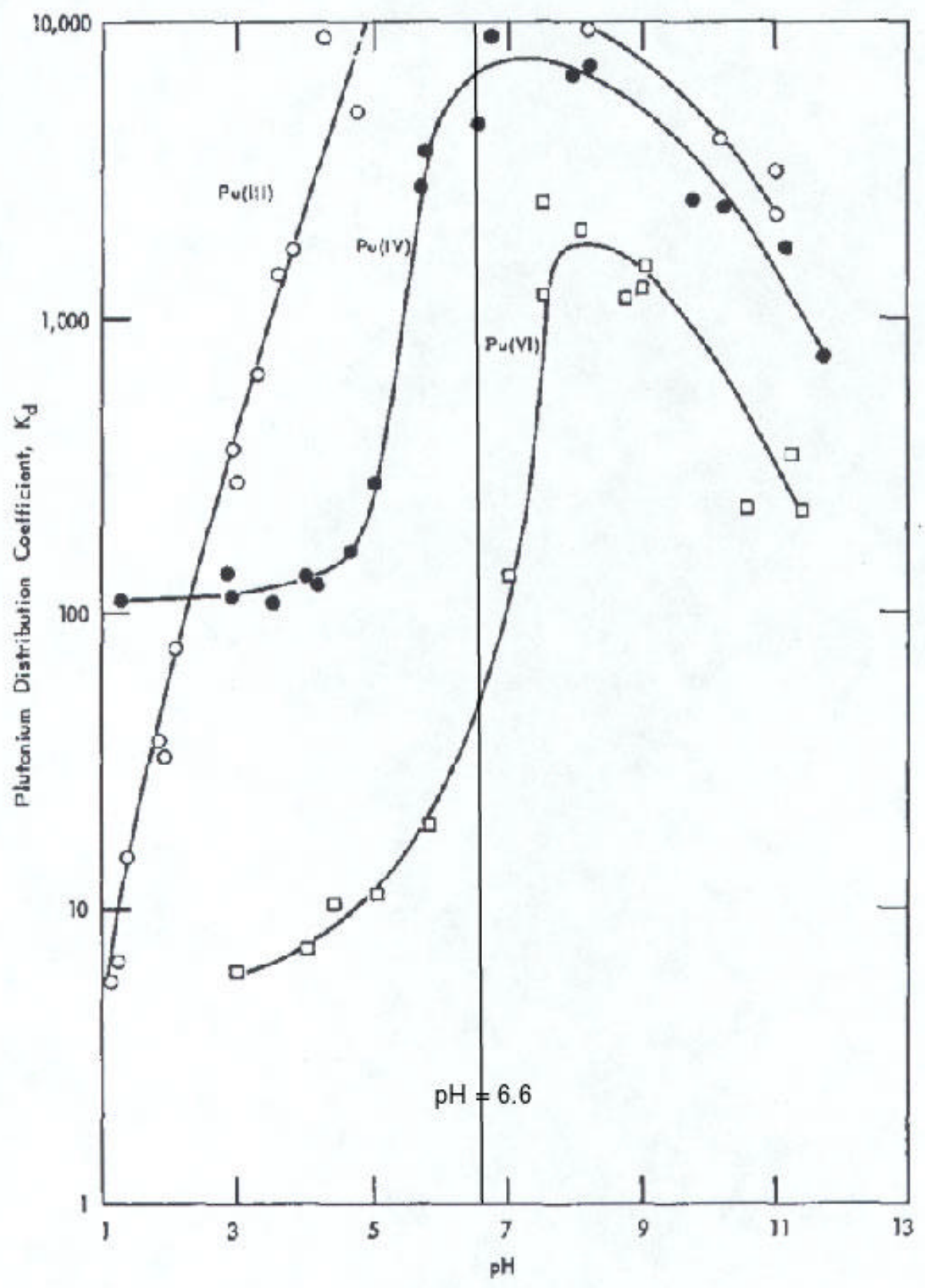


Figure 4. Percent Reduction of Calculated Plutonium Peak Concentration as a Function of Partition Coefficients

(Reduction relative to the case not including the sediment deposition/resuspension effect)

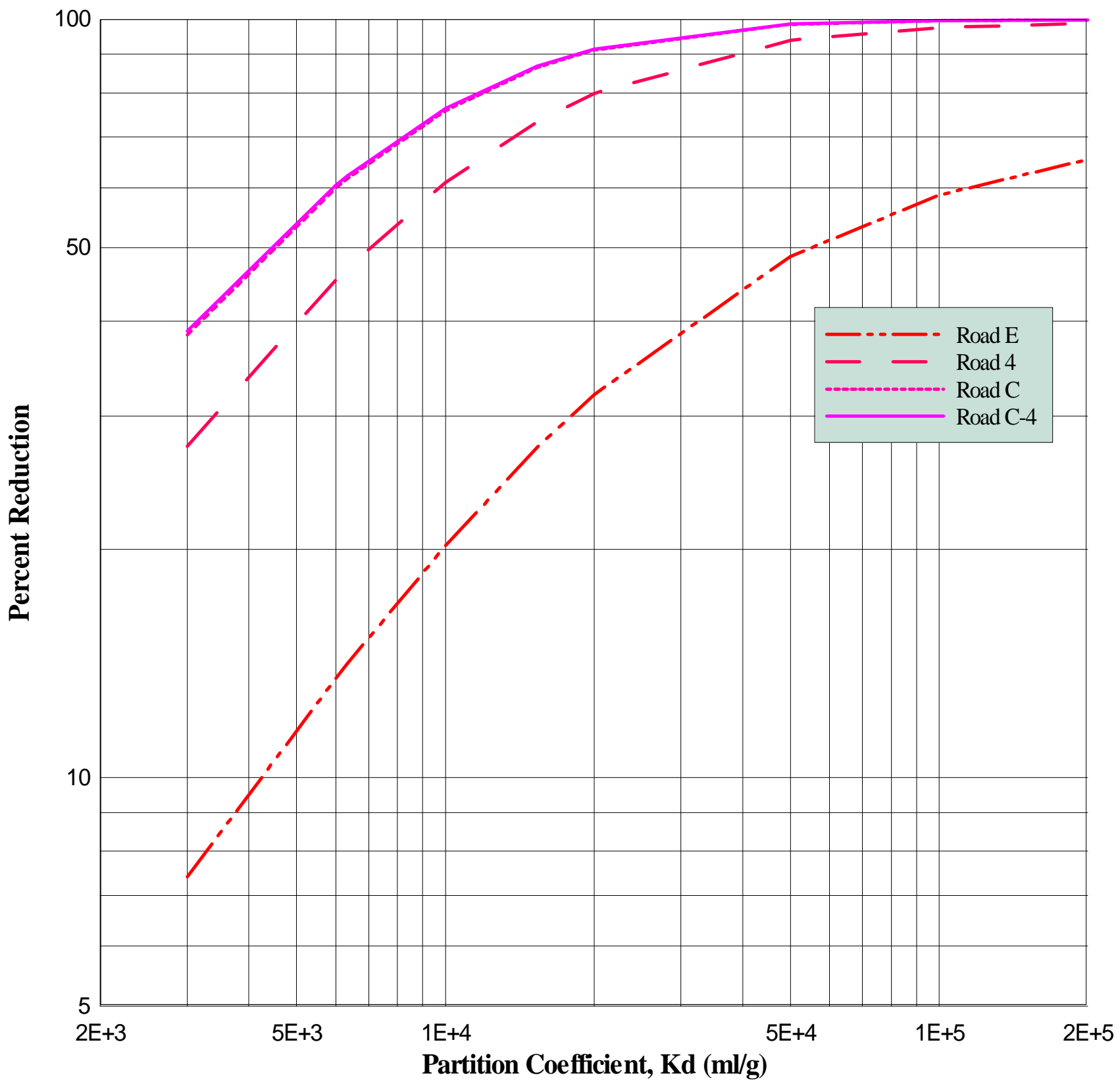


Figure 5 Relationship Between the Measured Radioactivity of Cs-137 and Pu-238 in the Fourmile Branch Sediment

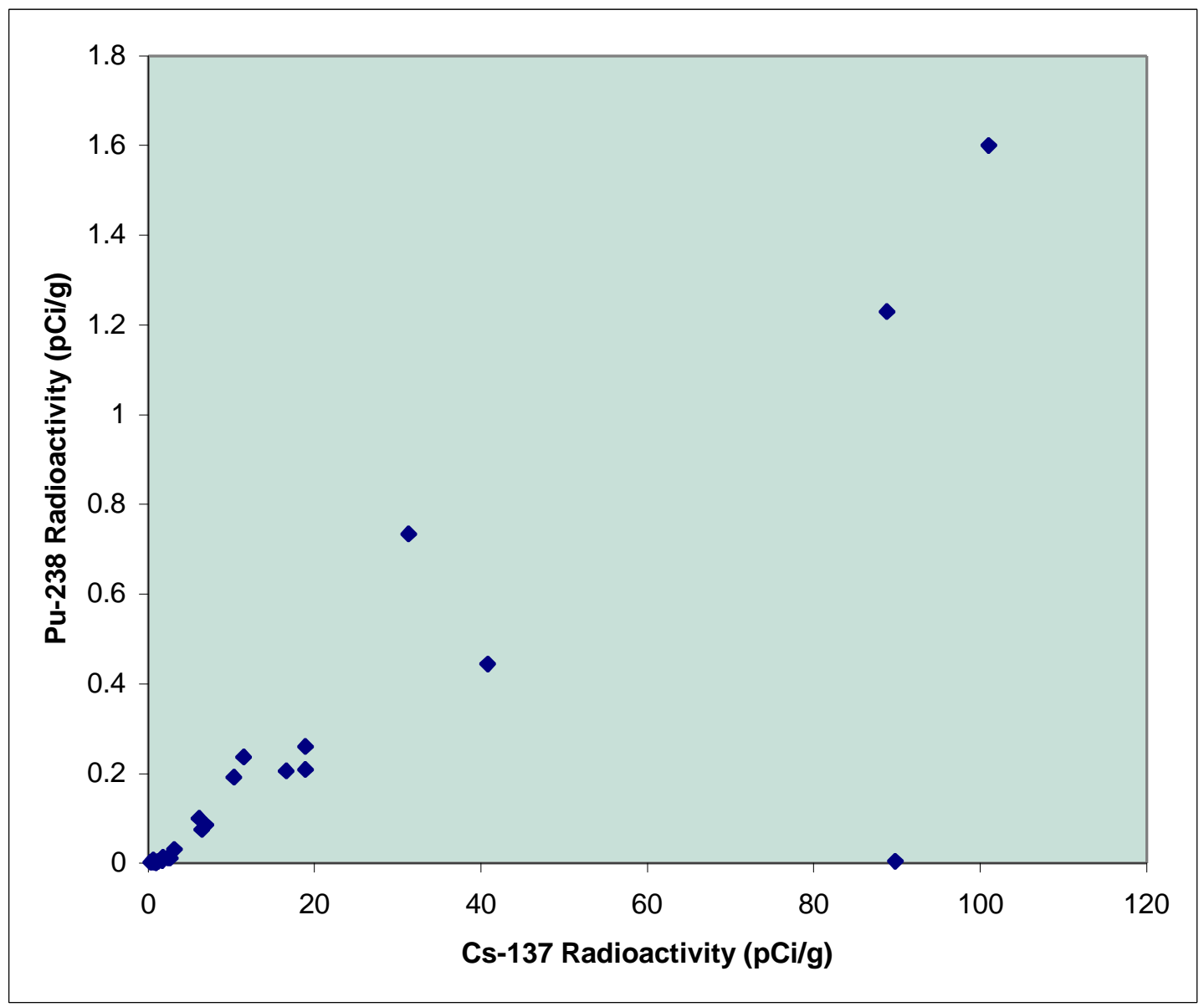


Figure 6. Relative annual fallout radionuclide inputs (lower histogram) and cumulative total input (upper histogram) for Lake Michigan, 1960-1974, and fraction of total Pu-239 and Cs-137 inputs remaining in the water during 1966-1974 (data points and straight lines)

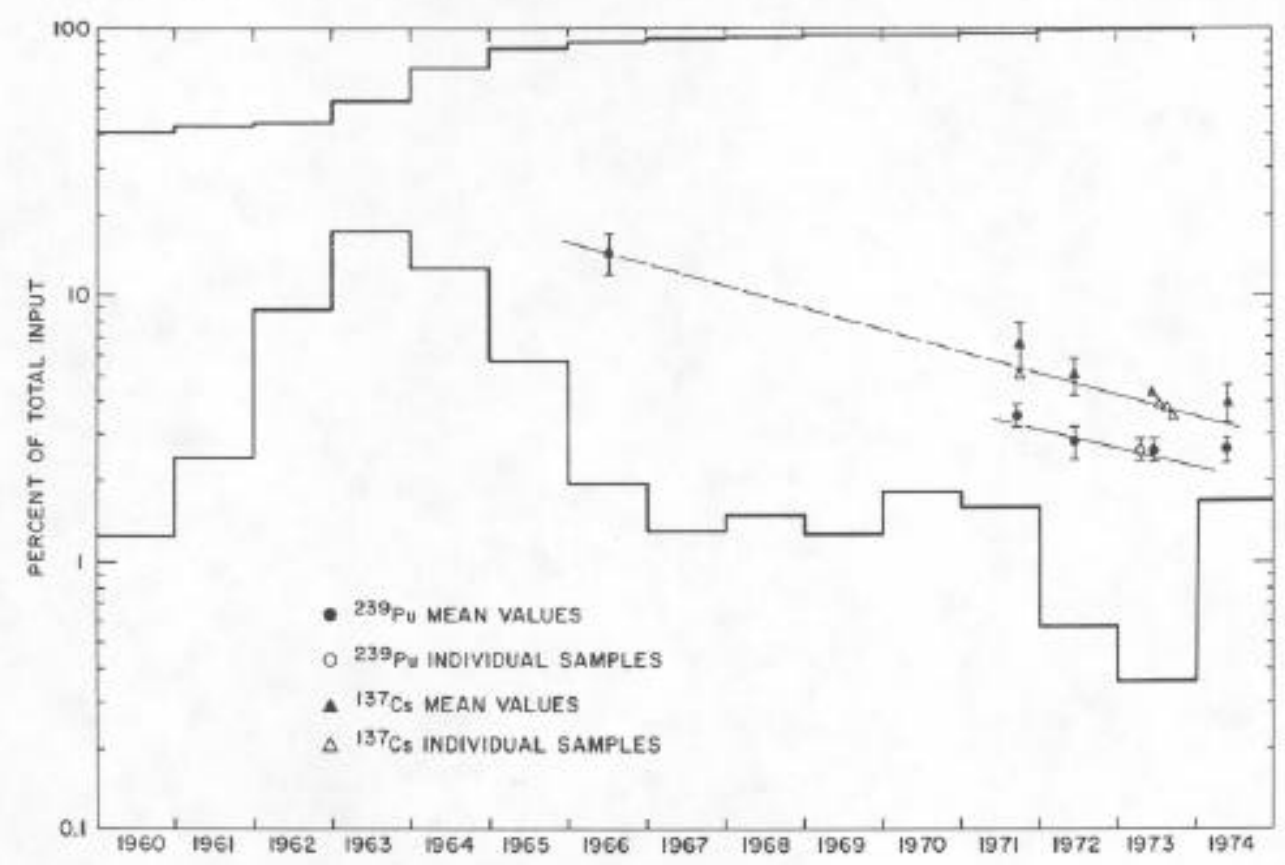

From Reference 21 
Figure 7. Curve Fit of the Cesium Partition Coefficient as a Function of Sediment Concentration (Data from Table 3)

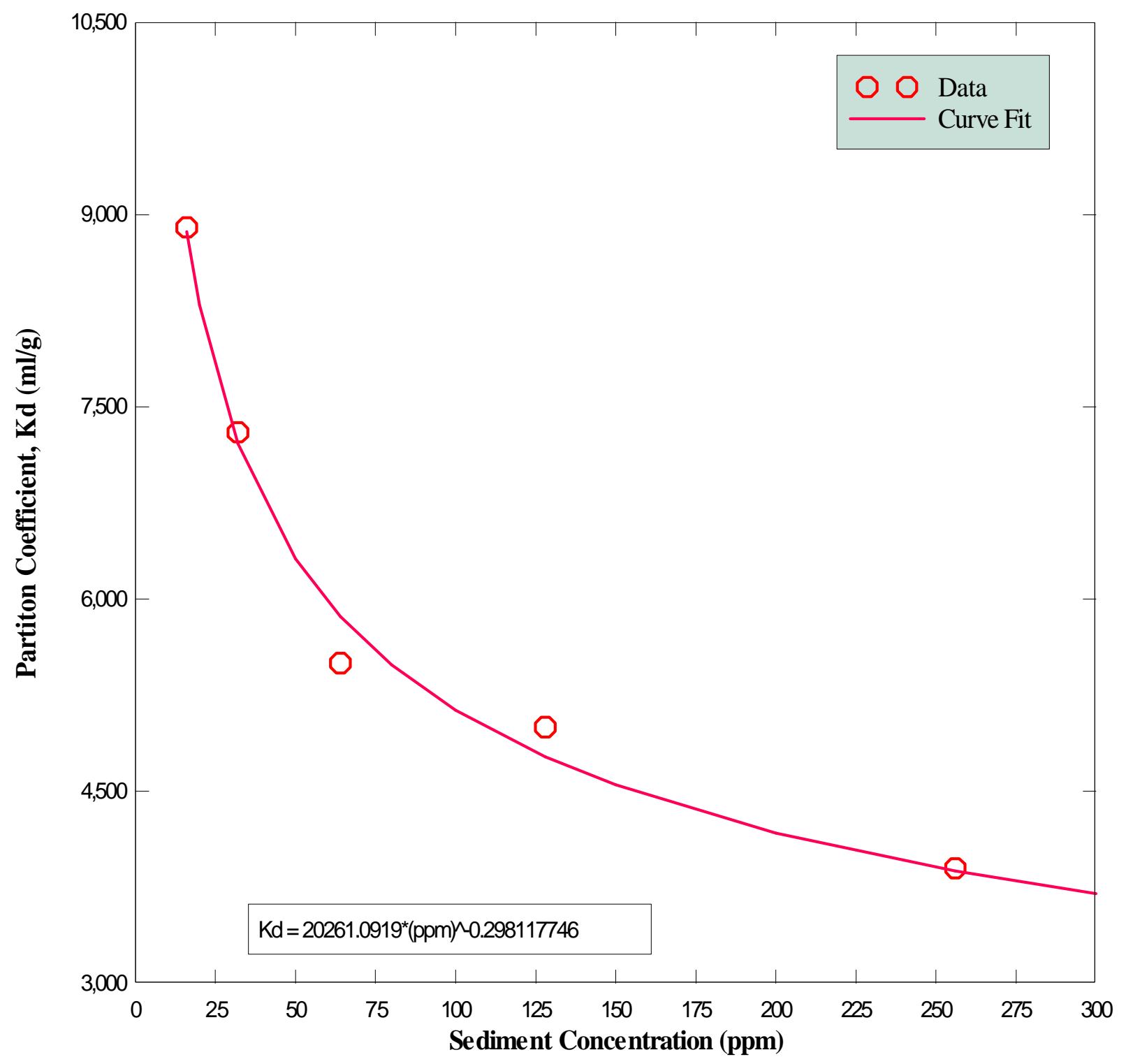

